\title{
9/11 AS FALSE FLAG: WHY INTERNATIONAL LAW MUST DARE TO CARE
}

\author{
Amy Baker Benjamin*
}

\begin{abstract}
At the heart of contemporary international law lies a paradox: The attacks on the United States of September 11, 2001 have justified sixteen years of international war, yet the official international community, embodied principally in the United Nations, has failed to question or even scrutinize the U.S. Government's account of those attacks. Despite the emergence of an impressive and serious body of literature that impugns the official account and even suggests that 9/11 may have been a classic (if unprecedentedly monstrous) false-flag attack, international statesmen, following the lead of scholars, have been reluctant to wade into what appears to be a very real controversy.

African nations are no strangers to the concept of the false flag tactic, and to its use historically in the pursuit of illegitimate geo-political aims and interests. This Article draws on recent African history in this regard, as well as on deeper twentieth century European and American history, to lay a foundation for entertaining the possibility of 9/11-as-false-flag. This Article then argues that the United Nations should seek to fulfill its core and incontrovertible "jury" function of determining the existence of inter-state aggression in order to exercise a long-overdue oversight of the official 9/11 narrative.
\end{abstract}

Key Words: False Flag, Pretextual Self-Defense, International Investigation, U.N. Jury Function

\section{INTRODUCTION}

No matter what one may think about the nature of the attacks that took place in the United States on September 11, 2001, one thing is beyond dispute: Those attacks have provided the legal, political and moral justifications for sixteen years of international war. Indeed, it is not an exaggeration to say that, with a few notable exceptions, all use-of-force roads laid since the beginning of this century lead back to the Rome of 9/11. These would Zealand

* Lecturer in Public International Law, Auckland University of Technology Law School, Auckland, New 
include the 2001 invasion and occupation of Afghanistan; the 2003 invasion and occupation of Iraq; the series of drone strikes here ${ }^{1}$ and cluster bombings there; ${ }^{2}$ the current mission to “degrade and defeat” the Islamic State and affiliated terror groups in Iraq and Syria; ${ }^{3}$ and even the quietly argued need to re-intervene in Libya now that it has become a "failed state" overrun by terrorists. ${ }^{4}$

Each one of these military campaigns and/or thrusts is based on the legal authorization and moral dispensation granted by domestic and international authorities in the days following 9/11 to respond to the attacks of that day. Ask today for the legal basis of fighting a global "War On Terror" against groups that were not even in existence in 2001, and you will be handed a copy of the law passed just seven days after 9/11 authorizing the President to use force against the perpetrators and abettors of 9/11 (i.e. Al-Qaeda and the Taliban). ${ }^{5}$ Challenge the wisdom of fighting a War On Terror to the end of a second decade, and you will likely be

1. See, e.g., Steve Coll, The Unblinking Stare - The Drone War in Pakistan, THE NeW YoRKER, Nov. 24, 2014.

2. See Amnesty International, Yemen: Images of Missile and Cluster Munitions Point to US Role in Fatal Attack, June 7, 2010, available at https://www.amnesty.org/en/press-releases/2010/06/yemen-images-missile-andcluster-munitions-point-us-role-fatal-attack-2010/ (date accessed 11/2/15).

3. Barack Obama, Letter from the President - Authorization for the Use of United States Armed Forces in connection with the Islamic State of Iraq and the Levant, Office of the Press Secretary, Feb. 11, 2015.

4. See Richard Lardner, The Top American General in Africa Says Libya Is a Failed State, U.S. News \& WORLD REPORT, March 8, 2016, https://www.usnews.com/news/politics/articles/2016-03-08/us-commander-inafrica-says-libya-is-a-failed-state; Giorgio Cafiero and Daniel Wagner, Four Years after Gaddafi, Libya Is a Failed State, FOREIGN POLICY IN FOCUS Apr. 6, 2015, http://fpif.org/four-years-after-gaddafi-libya-is-a-failed-state.

5. See 2001Authorization For Use of Military Force, P.L. 107-40; 50 U.S.C. § 1541 (Sept. 18, 2001) (“2001 AUMF”). The plain language of the 2001 AUMF authorizes the use of force only against groups and entities connected to the 9/11 attacks. However, it has been interpreted broadly by both the Bush and Obama administrations to permit the targeting of any group deemed to be affiliated or associated with Al-Qaeda in the years since 9/11 regardless of any lack of connection (or even possibility of connection) to the 9/11 attacks. See Matthew Weed, The 2001 Authorization for Use of Military Force: Background in Brief, CoNG. RES. SERV. (Jul. 10, 2013), https://www.fas.org/sgp/crs/natsec/aumf-071013.pdf (date accessed 11/2/15); see also Lauren Leatherby, Whatever Happened to the Debate Over Use of Force Against ISIS?, NAT’L PUBLIC RADIO, June 17, 2015, http://www.npr.org/2015/06/17/415203016/whatever-happened-to-the-debate-over-use-of-force-against-isis (date accessed 11/2/15). 
chided for inviting a terror attack on par with, or even worse than, 9/11. ${ }^{6}$ From the standpoint of international law and international political morality, then, 9/11 presumes to shoulder the heaviest of loads: A monumental amount of war to date, with apparently a good deal of war still to come. ${ }^{7}$

We would do well to remind ourselves, however, that this shouldering is only as strong and effective as the claim of self-defense on which it is based. The War on Terror is, after all, a war that is claimed to be fought in self-defense. ${ }^{8}$ Were this claim ever to be proved false were it ever to be shown that the United States was not in fact attacked by "others" on 9/11 but rather attacked itself (or let itself be attacked) for the purpose of blaming others and justifying international war - then its war would not be one of self-defense but of pre-meditated and

6. See, e.g., Al Kamen and Colby Itkowitz, Cheney Headed Back to the Hill, THE WASH. PosT, Sept. 8, 2014 ("In recent interviews, Cheney has issued dire warnings about ignoring the militant group [ISIL], saying inaction will result in an attack worse than 9/11"), https://www.washingtonpost.com/politics/cheney-headed-back-to-thehill/2014/09/08/1f18e940-378b-11e4-bdfb-de4104544a37_story.html (date accessed 11/2/15). The belief that 9/11 marked the beginning of a new order of terror, with an attack on a similar scale likely in the near future, has been called "the harbinger theory." See, e.g., RoBert DiAB, The HARBInger TheOry: How ThE POST-9/11 Emergency BeCAme PERmanent And The CASE For Reform (Oxford Univ. Press 2015).

7. See Charlie Savage, Debating the Legal Basis for the War on Terror, THE N.Y. TIMES, May 16, 2013 (“A top Pentagon official said Thursday that the evolving war against Al Qaeda was likely to continue 'at least 10 to 20 years' and urged Congress not to modify the statute that provides its legal basis"), http://www.nytimes.com/2013/05/17/us/politics/pentagon-official-urges-congress-to-keep-statute-allowing-waron-terror-intact.html? $r=1$ (date accessed 11/2/15). 9/11 also continues to do considerable heavy lifting in U.S. domestic politics. When asked to explain her close financial ties to Wall Street during the 2016 Presidential campaign, Hillary Clinton replied:

So I represented New York, and I represented New York on 9/11 when we were attacked. Where were we attacked? We were attacked in downtown Manhattan where Wall Street is. I did spend a whole lot of time and effort helping them rebuild. That was good for New York. It was good for the economy, and it was a way to rebuke the terrorists who had attacked our country.

Mike Krieger, A New Low? Hillary Clinton Claims 9/11 Is the Reason She's Owned by Wall Street, LIBERTY BLITZKRIEG BLOG, Nov. 15, 2015, http://libertyblitzkrieg.com/2015/11/15/a-new-low-hillary-clinton-claims-911is-the-reason-shes-owned-by-wall-street/ (date accessed 11/17/15).

8. See 2001 AUMF, supra note XX ("Whereas, on September 11, 2001, acts of treacherous violence were committed against the United States and its citizens; and Whereas, such acts render it both necessary and appropriate that the United States exercise its rights to self-defense and to protect United States citizens both at home and abroad ... ”) ); Derek Jinks, September 11 and the Laws of War, 28 YALE J. INT’L L. 1-49, 6 (2003) (U.S. military action in Afghanistan was "predicated on the claim that the September 11 attacks constituted or foretold subsequent 'armed attacks' within the meaning of the U.N. Charter.") (footnote omitted). 
carefully camouflaged aggression. $^{9}$ In this sensitive matter especially, the obvious bears repeating: "[I]f 9-11 is in fact an instance of Machiavellian state terror . . . then any US pretence that these wars have to do with self-defense is totally unsustainable.” 10

Precisely because so much is at stake, one might expect international institutions such as the United Nations to seek to satisfy themselves that the American claim of self-defense is a valid one. Yet remarkably enough they have never shown an interest in doing so. In the days and weeks following 9/11, the U.N. accepted without hesitation the American claim to have been attacked by elements of international terrorism. ${ }^{11}$ NATO more or less followed suit, even though the peremptory nature of its mutual-defense pact obliged it to probe the validity of the American self-defense claim, not merely rubber-stamp it. ${ }^{12}$ Over the course of the last sixteen years, neither the U.N. nor NATO has revisited the issue of responsibility for the attacks, and this despite the fact that (a) an impressive body of literature has emerged that challenges

9. A "false flag attack" occurs when a country organizes an attack on its own citizens and/or officials and makes the attack appear to be by enemy nations, political opponents or terrorists, thereby giving the country a pretext for domestic repression and/or foreign militaryaggression. I will use here a broadened definition of the term that also includes foreign attacks "that a government knew were coming and could have stopped but allowed to succeed so that the nation would be primed for war." LANCE DEHAVEN-SMITH, CONSPIRACY THEORY IN AMERICA (U.Texas Press 2013), at 226.

10. David MacGregor and Paul Zarembka, Marxism, Conspiracy and 9-11, 24 SoCIALISM AND DEMOCRACY 139-63, 142 (2010).

11. See S.C. Res. 1368, 4370th mtg., UN Doc S/RES/1368 (Sept. 12, 2011); S.C. Res 1373, 4385th mtg., UN Doc S/RES/1373 (Sept. 28, 2001).

12. On September 12, 2001, NATO’s governing body authorized invocation of Article 5 of NATO’s Charter which states than an armed attack on one member shall be regarded as an armed attack on all - subject to the evidentiary caveat, "if it is determined that this attack was directed from abroad against the United States." NATO Press Release (2001) 124, Statement by the North Atlantic Council (Sept. 12, 2001). Three weeks later, NATO Secretary General Lord Robertson reported that this evidentiary requirement had been satisfied on the basis of "clear and compelling" evidence presented by the United States showing that the 9/11 attacks had been the work of Al-Qaeda, as protected by the Taliban. Statement by NATO Secretary-General Lord Robertson, Brussels, Belgium (Oct. 2, 2001). However, there appears to have been no independent investigation by NATO authorities into the facts surrounding the $9 / 11$ attacks. The evidence referred to by Lord Robertson, such as it was, appears to have come solely from U.S. Government sources in the form of closed-door briefings. 
virtually every significant aspect of the official account; ${ }^{13}$ (b) key members of the United States

Congress have insisted that the domestic investigations into 9/11 were not credible and, indeed, were "set up to fail” by the Bush II Administration; ${ }^{14}$ and (c) two candidates for the office of U.S. President in 2016 - Donald Trump (Republican Party) and Jill Stein (Green Party) -

13. A small sampling of (purely English-language) alternative 9/11 literature and commentary might include: Stephen Jones, et al., 15 Years Later: On the Physics of High-Rise Building Collapses, 47 EUROPHYSICS NEWS 21 (2016), http://www.europhysicsnews.org/articles/epn/pdf/2016/04/epn2016-47-4.pdf ("[T]he evidence points overwhelmingly to the conclusion that all three [World Trade Center] buildings were destroyed by controlled demolition. Given the far-reaching implications, it is morally imperative that this hypothesis be the subject of a truly scientific and impartial investigation by responsible authorities.”) (emphasis added); The 9/11 Best Evidence Panel, The 9/11 Consensus Points (2016), http://www.consensus911.org/the-911-consensus-points/; Paul Craig Roberts, 9/11 After 13 Years (2014), http://www.paulcraigroberts.org/2014/09/10/911-13-years-paul-craig-roberts/; JAMES Gourley (ed.), THE 9/11 TORONTO REPORT: INTERNATIONAL HEARINGS ON THE EVENTS Of SEPTEMBER 11, 2001 (International Center for 9/11 Studies 2013); ELIAS DAVIDDSON, HIJACKING AMERICA’S Mind On 9/11: Counterfeiting Evidence (Algora Publishing 2013); Kevin R. Ryan, ANOTHER NineteEn: Investigating LEgITIMATE 9/11 Suspects (Microbloom 2013); CHRISTOPHER LEE BOLLYN, SOlVING 9-11: THE DECEPTION THAT CHANGED THE WORLD (2012); E.P. HEIDNER, COLLATERAL DAMAGE: U.S. COVERT OPERATIONS AND THE TERRORIST ATTACKS ON SEPTEMBER 11, 2001, Sept. 1, 2010, https://www.scribd.com/doc/9442970/Collateral-Damage-U-S-Covert-Operations-and-the-Terrorist-Attacks-onSeptember-11-2001-28062008; PAUl ZAREMBKA (ed.), THE HidDEN HisTORY OF 9/11 (Seven Stories Press 2008); DAVID R. GRIFFIn and PETER D. SCOTt (eds.), 9/11 AND AMERICAN EMPIRE: INTELlECTUALS SPEAK OUT (Olive Branch Press 2007); BArrie Zwicker, Towers Of Deception: The Media Cover-Up Of 9/11 (New Society Publishers 2006); Allen M. Poteshman, Unusual Option Market Activity and the Terrorist Attacks of September 11, 2001, 79 J. Bus. 1703-26 (2006); Michael C. Ruppert, Crossing The Rubicon: The Decline Of ThE American Empire At The End Of The Age Of Oil (New Society Publishers 2004); DAvid R. GRIfFIn, The New Pearl Harbor: Disturbing Questions About The Bush Administration And 9/11 (Olive Branch Press 2004). In addition to these texts, The Journal of 9/11 Studies, edited by Kevin R. Ryan, publishes peerreviewed articles that challenge many aspects of the official 9/11 narrative.

14. Writing in The Guardian in 2007, British journalist Peter Thatchell noted:

The chair and vice chair of the 9/11 Commission, respectively Thomas Kean and Lee Hamilton, assert in their book, "Without Precedent," that they were "set up to fail" and were starved of funds to do a proper investigation. They also confirm that they were denied access to the truth and misled by senior officials in the Pentagon and the federal aviation authority; and that this obstruction and deception led them to contemplate slapping officials with criminal charges.

Despite the many public statements by $9 / 11$ commissioners and staff members acknowledging they were repeatedly lied to, not a single person has ever been charged, tried, or even reprimanded, for lying to the 9/11 Commission.

Peter Thatchell, 9/11 - The Big Coverup?, Sept. 12, 2007, https://www.theguardian.com/commentisfree/2007/sep/12/911thebigcoverup. See also Washington Blog, U.S. Government Intentionally Destroys 9/11 Evidence, GLOBAL RESEARCH (Sept. 4, 2016), http://www.globalresearch.ca/us-government-intentionally-destroys-911-evidence/5529058; Benjamin DeMott, Whitewash As Public Service: How the 9/11 Commission Report Defrauds the Nation, HARPER'S MAGAZINE, Oct. 2004. 
publicly questioned the accuracy of the official account, with Stein going so far as to call for a new investigation. ${ }^{15}$

The reluctance to ask hard questions in the halls of international institutions charged with the duty to vet claims of national self-defense has been matched by the silence of scholars, who have almost uniformly shied away from the 9/11 controversy swirling outside their halls. ${ }^{16}$ This is not to say that scholars have avoided 9/11 as a topic of study. Quite the contrary - they have embraced it, but only so far, and only in a highly circumscribed manner. Scholars specializing in international law or international relations, for example, have generated a multitude of articles and books on 9/11, but almost all such studies assume the correctness of the core U.S. claim of self-defense and then proceed to nibble on issues lying around its perimeter. How much should we sacrifice our civil liberties in order to better safeguard our security? Can the 9/11 attacks support a paradigm shift away from anticipatory self-defense to preventative self-defense? Might the torture of terror suspects be justified on a "warfare" approach to counter-terrorism as opposed to a “crime” approach (and vice versa)? These are all

15. See Donald Trump, Remarks at Campaign Rally in Bluffton, South Carolina on February 17, 2016, https://www.youtube.com/watch?v=j-7bxI XOoQ; Harper Neidig, Jill Stein Calls for New 9/11 Investigation, THE HILL (Sept. 9, 2016), (http://thehill.com/blogs/ballot-box/presidential-races/295266-stein-calls-for-new-9-11investigation.

16. See Roger Roots, Who Benefits from Terrorism: The Common Interests of Terrorists and Governments of Terrorized Societies, 5 WAR CRIMES, GENOCIDE, AND CRIMES AgAINST HuMANITY 125-45, 137 (2011) (noting that alternative 9/11 literature is "noteworthy both for its popularity among readers and for its nonrecognition among academic sources”); Carolyn Baker, 9/11 and American Empire: Intellectuals Speak Out , GLOBAL RESEARCH NEWSLETTER (Jan. 20, 2007) (noting "higher education's abject paranoia regarding skepticism of the official story of 9/11"), http://www.globalresearch.ca/9-11-and-american-empire-intellectuals-speak-out-by-davidray-griffin-and-peter-dale-scott/4538 (date accessed 11/4/15); see also DEHAVEN-SMITH, supra note 9, at 13 ("Social scientists have studied various forms of state crime, but in almost every case the potential for public officials in liberal democracies to subvert democratic institutions has been disregarded.”); Richard Jackson, The Ghosts of State Terror: Knowledge, Politics and Terrorism Studies, 1 CRITICAL STUDIES On TERRORISM 377-92, 380-81 (2008) (" [T] There are a great many prominent scholars who acknowledge in passing that terrorism is a strategy of political violence which any actor can employ, including states, but then do not examine cases of state terrorism in any systematic or sustained manner in their research....[A] discourse analysis of [introductory terrorism] texts reveals ... a deep and pervasive silence on Western democratic state terrorism ....") 
good and worthwhile questions, but they do exhibit a tendency to uncritically assume the accuracy of the official 9/11 account.

Recent developments suggest that the public at large is beginning to back away from this assumption, and that it may be time for scholars to do so as well. Bowing to public pressure, the Obama Administration declassified a twenty-eight-page excerpt from a 2002 Congressional report on the 9/11 attacks that strongly indicates that officials and operatives of the Government of Saudi Arabia funded and logistically choreographed the hijackers involved in the attacks. ${ }^{17}$ Several months after this declassification, the U.S. Congress enacted legislation that enables families of 9/11 victims to sue the Saudi Government for damages for any acts of terrorism on U.S. soil shown to have been sponsored by it. ${ }^{18}$ Given the close geostrategic alliance between the U.S. and Saudi Arabia, as well as the lesser known but equally close historical ties between the Saudi royal family and the Bush political dynasty, ${ }^{19}$

17. See Philip Shenon, Release of 9/11 Report Could Strain US Relationship with Saudi Arabia, THE GUARDIAN (July 16, 2016), https://www.theguardian.com/us-news/2016/jul/16/911-report-release-saudi-arabia-usrelations. Writes Shenon:
The so-called '28 pages' suggest a much larger web of connections between al- Qaida and the Saudi royal family than had previously been known ... . John Lehman, navy secretary in the Reagan administration and a Republican member of the 9/11 commission, said in an interview on Friday that the 28 pages, which he had not read for several years, demonstrated why there needed to be additional investigation of the possible ties between Saudi government officials and the $9 / 11$ plot.

See also Larisa Alexandrovna Horton, The ' 28 Pages' Explained, AnTIWAR.Com (July 21, 2016) ("The 28 Pages make it clear that the hijackers had handlers who were reporting to, funded by and taking directions from figures at the highest levels of the Saudi government"), http://original.antiwar.com/larisa-alexandrovna/2016/07/20/28-pagesexplained; CBS Evening News, "Senator Urges Obama to Declassify Part of 9/11 Report” (April 9, 2016) (former Senator Bob Graham reveals - prior to declassification - that the 28 Pages outlined a network of Saudi charities, wealthy nationals, and government officials that supported the 9/11 hijackers while they were in the U.S.), https://www.youtube.com/watch?v=TOu1eF_uQsE.

18. See,David Smith, Congress Overrides Obama's Veto of 9/11 Bill Letting Families Sue Saudi Arabia, THE GUARDIAN (Sept. 29, 2016), https://www.theguardian.com/us-news/2016/sep/28/senate-obama-veto-september11-bill-saudi-arabia.

19. See, e.g., Russ BAKer, FAmily Of SECrets: The Bush Dynasty, America’s Invisible Government, And The Hidden History Of The LAst FifTy YeARs (Bloomsbury Press 2009). 
evidence implicating elements of the Saudi Government should prompt uncomfortable questions regarding the actions of Saudi-friendly elements within the U.S. Government at the time of the 9/11 attacks. At the very least, a Saudi role in the attacks would invalidate the core plank of the official account - namely, the claim that a decentralized group of non-state actors, bent on the most indiscriminate kind of asymmetric warfare, perpetrated the attacks on their own and unaided by the resources of any nation-state.

This belated and still-fledgling American movement toward transparency regarding 9/11 is unquestionably laudable. It is also, however, insufficient. The main contention of this Article is that international law and international political institutions have a vital role to play in ensuring that the case of 9/11 is fully and objectively investigated. My argument is based on the late Professor Thomas Franck's insistence that the core mission of the premier public international body - the United Nations - is to perform its “jury” function of determining and declaring whether an act of aggression has occurred. ${ }^{20}$ Pretextual self-defense based on a false flag event is almost by definition aggression, as it constitutes an act of force resting on a spurious justification. Even if the collective-security role of the U.N. system - as reflected in the second half of Article 39, Articles 41 and 42 of the Charter - seems to have withered on the vine and to be now worth little, the U.N.’s jury role, as reflected in the first half of Article 39, remains firmly intact. (Importantly, and as I will show below, this is true regardless of whether this jury role is viewed as being rooted in the positive law of Article 39 or in pre-Charter customary international law.) For the U.N.'s political organs ${ }^{21}$ to remain disengaged from the controversy surrounding $9 / 11$ is to abdicate responsibility for their core mission. It is, in a very

20. See Thomas M. Franck, When, If Ever, May States Deploy Military Force Without Prior Security Council Authorization, 5 WASH. U. J. L. POL'Y 51, 68 (2001).

21. The Security Council and the General Assembly 
real and practical sense, to deny their own raison d'etre. This, indeed, is an outcome to be avoided if at all possible.

But is it possible? Can the U.N.finally, after all these years, muster the will to pass judgment on the U.S. claim to have been the victim of international terrorism on 9/11? They certainly can, but they obviously need some help: The case of 9/11-as-false-flag is so fraught with anger and ignorance as to be almost paralyzing. Whether we passively listen or actively turn away, all that many of us hear are disturbing sounds and cries claiming to have evidence of unspeakable acts. Historical events that lie more deeply in the past, however, are less threatening, and therefore more instructive. And so I will suggest that the first step in trying to break the 9/11 paralysis is to recognize that international law and political institutions have long been concerned with the danger of nation states committing false flags in order to both gain domestic political advantage and/or to justify (or prepare for) international war. To portions of this unsavory history I now turn.

\section{PART I}

\section{WHY IT IS RATIONAL TO CARE}

\section{A. Africa’s False Flag “Education”}

The continent of Africa regrettably needs no lessons in the reality of the false-flag tactic and of its use in the pursuit of illegitimate political aims. There is, to begin with, the unfortunate example of the Apartheid regime in South Africa, under which South African security services stealthily carried out attacks against government officials and installations for the purpose of blaming the African National Congress and thereby discrediting the antiApartheid movement as a whole. The routine nature of these attacks is attested to by the sheer number of times the post-Apartheid South African Truth and Reconciliation Commission had to 
use the term "false flag" in the course of deciding the amnesty applications of white South

African former officials. Consider the Commission's ruling in the case of Charles Alfred

Zeelie (“applicant”), hardly exceptional:

These incidents [bomb explosions at Joubert Park and J.G. Strydom Hospital in Johannesburg] happened on 27 July 1989. Applicant was not a party to the perpetration of the actual incidents. To his knowledge, however, some of his colleagues in the South African Police were responsible for the incidents which were false flag operations. Applicant held the position of head of the Bomb Disposal Unit at Witwatersrand at the time. It was in this capacity that he was involved in aiding the objective of the operations which were aimed at discrediting the African National Congress ("ANC") by creating the impression that the organisation was responsible for the explosions. Applicant's specific role was to visit the sites of the explosions on investigation in his capacity as an explosives expert and later submitting false statements supporting the impression that the explosives were caused by operatives of the ANC. . .

[A second incident] happened during 1989. The circumstances briefly were that Applicant was ordered by his superiors to participate in a false flag attack upon the headquarters of the Flying Squad in Brixton, Johannesburg. The objective was to create the impression that the ANC was responsible for the attack. The incident occurred shortly prior to the all-white referendum and the intention was to discredit the ANC among the white electorate. A RGD-5 hand grenade and an AK-47 assault rifle were utilised in the attack. Applicant and a group of his colleagues drove past the offices of the Flying Squad and caused the hand grenade to explode near the entrance. They also fired shots at the wall near the entrance with the AK-47 assault rifle. ${ }^{22}$

Farther to the North, in Algeria, the Algerian government has long stood accused of covertly murdering innocent civilians and then blaming such murders on popular Islamic political parties in order to discredit them during the country’s brutal civil war of the 1990s.

Notes one Western analyst:

Many of these 'operations' [acts of violence attributed to political Islamicists] were 'false flag' operations, operations secretly conceived

22. Application for Amnesty of Charles Alfred Zeelie (AM3751/96), Truth and Reconciliation Commission (2001), http://www.justice.gov.za/trc/decisions\%5C2001/ac21233.htm (emphasis added). 
and implemented by the Algerian government itself, with the knowledge of the ruling clique to make the country's Islamic movement look far worse than it was in actual fact. Committing acts of brutality, in actual fact carried out by the government but in the name of Islamic militants, helped to isolate the Islamic movement at the time from its popular base, provoke intense fear among a population that would then ask for stronger security measures, i.e., a more repressive hold on the country by the state. ${ }^{23}$

No less an establishment institution than the U.S.-based Brookings Institution would seem to agree with this assessment, curtly acknowledging in a 2013 report that Algerian intelligence has long been "known for its tactic of infiltrating terrorist groups, creating 'false flag' terrorists and trying to control them.” ${ }^{24}$ Families of the victims of these false flag attacks have insistently sought to bring the perpetrators to justice in France, which is receptive to adjudicating the claims, given some indifference and even obstruction shown by the Algerian government itself. $^{25}$

The South African and Algerian experiences with false-flag violence are enlightening in two ways. First, they afford us a lesson in political morality. They show that the answer to false-flag violence is not to turn away from it in fear and denial but to stare it squarely in the face for the ugly creature that it is and deal with it as the circumstances of each case warrant. Second and of equal importance, these experiences place African scholars and statesmen in a

23. Rob Prince, Algeria's Trappist Monk Massacre: The Case That Won't Go Away, June 27, 2013 http://www.ips-dc.org/algerias trappist monk massacre the case that wont_go away. See also Yasmine Ryan, Uncovering Algeria's Civil War, Nov. 18, 2010 ("Key to the strategy [of the Algerian Government] were false flag operations and misinformation casting political opponents as ruthless terrorists, while genuine opponents of the regime were 'eradicated' - their killings often blamed on 'Islamists.'”), http://www.aljazeera.com/indepth/2010/11/2010118122224407570.html.

24. Bruce Riedel, Algeria A Complex Ally In War Against al Qaeda, Feb. 3, 2013, http://www.brookings.edu/research/opinions/2013/02/03-algeria-riedel.

25. See Ryan, supra note 23. 
unique position to fully appreciate the significance of a twentieth century history (described below) that is rife with the use of the false flag tactic to justify international war.

\section{B. Manchuria, Reichstag Fire, Gleiwitz}

From the start of the Cold War through to the present day, international political and legal bodies have had to deal with many problematic claims of national self-defense. However, almost all such claims have involved acts of either anticipatory self-defense ${ }^{26}$ or collective selfdefense/counter-intervention. ${ }^{27}$ This can obscure the fact that during a more distant time period - namely, the twenty-year interregnum of the inter-war period and the immediate aftermath of World War II - international concern was focused to a large extent on pretextual claims of selfdefense based on false flag attacks.

It is sobering to recall that the first major crisis to strike the U.N.’s predecessor organization, the League of Nations, was an international invasion by one state of another based on a highly dubious claim of having been attacked. In 1931, Japan invaded the northeastern Chinese province of Manchuria, claiming that Chinese nationalists had sabotaged portions of a railway line controlled and operated by it near the city of Mukden. Though the explosion was so weak that it failed to destroy the track, the Japanese Army immediately accused Chinese dissidents of the attack and responded with a full-scale invasion that led to the occupation of Manchuria, and the installation of a puppet regime, within six months. Historian Walter LaFeber makes short work of any doubts as to what actually occurred:

[In the hours immediately following the explosion], [f]ighting broke out between Japanese and Chinese troops. By morning, the [Japanese] Army held Mukden and was expanding its control over surrounding

26. E.g. Israel's bombing of Iraq's nuclear reactor in 1981 and the U.S. naval blockade of Cuba in 1962.

27. See, e.g., Military and Paramilitary Activities In and Against Nicaragua (Nicar. v. U.S.), 1986 ICJ Rep. 14 (June 27). 
territory. Its officers claimed that the bomb had been set by the Chinese and even conveniently spread several Chinese bodies around the explosion site. But authorities in Tokyo and other world capitals quickly concluded that the army had blown up its own railway tracks as an excuse to conquer Manchuria. ${ }^{28}$

Upon China's complaint of illegal aggression by Japan, the League of Nations seized itself of the matter and sent a commission to Manchuria to investigate. Although remarkably even-handed in its assessment of blame for the generally tense situation in Manchuria between the Japanese Army and the Chinese populace, the Lytton Commission voiced strong skepticism of Japan's claim of having been the victim of aggression:

The Japanese, as was explained to the Commission in evidence, had a carefully prepared plan to meet the case of possible hostilities between themselves and the Chinese. On the night of [the explosion] this plan was put into operation with swiftness and precision. The Chinese ... had no plan of attacking the Japanese troops or of endangering lives or property of Japanese nationals at this particular time or place. They made no concerted or authorized attack on the Japanese forces and were surprised by the Japanese attack and subsequent operations. An explosion undoubtedly occurred on or near the railroad between 10 P.M. and 10:30 P.M. on September 18, but the damage, if any, to the railroad did not in fact prevent the punctual arrival of the south bound train from Changchun and was not in itself sufficient to justify military action. The military operations of the Japanese troops during this night ... cannot be regarded as measures of legitimate self defense. In saying this the Commission does not exclude the hypothesis that the officers on the spot may have thought they were acting in self defense. ${ }^{29}$

\footnotetext{
28. Walter LaFeber, The Clash: A History OF U.S.- JAPAN Relations (W.W. Norton \& Co. 1997), at 166 (footnote omitted).

29. Memorandum on the Report of the Lytton Commission, 1 Institute Of PACIFIC Relations, AmERICAN CouncIL 2-3 (Oct. 7, 1932) (emphasis added). Needless to say, in being open to the possibility that "officers on the spot" may have thought they were acting in self-defense, the Commission hardly implied exoneration of higher-level Japanese officers who were not present on the ground during the night of the explosion and who would have been the ones to orchestrate the event.
} 
However mild the rebuke, the Japanese knew an insult when they heard one and abruptly withdrew from the League in $1933 .{ }^{30}$ Years later, following the carnage of Japanese aggression during World War II, the Tokyo International Military Tribunal heard evidence on the Mukden Incident and forthrightly concluded what the Lytton Commission had been too gentlemanly to state:

The evidence is abundant and convincing that the 'Mukden Incident' was carefully planned beforehand by officers of the Army General Staff, officers of the Kwantung Army, members of the Cherry Society, and others....The Tribunal rejects the Japanese contention and holds that the so-called 'Incident' of 18 September 1931 was planned and executed by the Japanese. ${ }^{31}$

This, then, was the sneaky face of aggression in a world where aggressive war had ceased to be regarded as a legitimate instrument of national policy. As the Japanese well understood, by 1931 a state could no longer legitimately say, "We want their territory, let’s take it” - as Germany had effectively said to France sixty years earlier, in 1870, when it had gobbled up French-owned Alsace-Lorraine in a bid to craft a unified German nation-state. ${ }^{32}$ No, by 1931 - courtesy of the League’s collective-security system and the 1928 Kellogg-Briand Pact, which denied states the right to wage aggressive war $^{33}$ - a nation would have to fake it in order to get away with it.

30. Stuart Brown, Japans Stuns World, Withdraws From League, UNITED PRESS INT’L, Feb. 24, 1933, http://100years.upi.com/sta_1933-02-24.html (date accessed 11/16/15).

31. NeIl Boister \& Robert Cryer (eds), DOCuments On The TOKyo InTERnAtional Military TRIBUNAL (Oxford U. Press 2008), at 321-22 (internal quotation marks in original).

32. In his memoir, Prussian Chancellor Otto von Bismarck remarked: "I did not doubt that a Franco-Prussian War must take place before the construction of a United Germany could be realised." Otto von Bismarck (A.J. Butler, trans.), BismarcK: THE MAN And ThE STATESMAn, Vol. 2 (originally published in 1898; reprinted in 2007 by Cosimo Classics, New York), at 58.

33. General Treaty for the Renunciation of War As an Instrument of National Policy, arts. I-II, Aug. 27, 1928, 46 Stat. 2343, 94 L.N.T.S. 57. 
Hitler, of course, had been watching and taking notes on Manchuria, and when he decided to invade Poland in 1939, he felt he needed to create a veneer of self-defensive indignation before sending his already-primed army over international borders. Thus ensued what has come to be known as the "Gleiwitz Incident:" To create the appearance of Polish aggression against Germany, Hitler’s lieutenants had German troops dress up as Poles and attack German installations along the German-Polish border.

[By August 1939 Hitler] was left with no alternative but to attack Poland and to fight England and France as well. Still he had no excuse for war. The Poles were not threatening Germany with military force; it was Germany who was rattling the saber. Lacking an excuse, Hitler proceeded to fabricate one.

Early in August, 1939, a plan had been conceived for this purpose by the Chief of the Security Police and SD, Heydrich, to stage simulated border raids by personnel of the Gestapo and SD dressed as Poles. To add authenticity, it was planned to take certain prisoners from concentration camps, kill them by the use of hypodermic injections, and leave their bodies, clad in Polish uniforms, at the various places where the incidents supposedly were to occur. On August 31 these 'border incidents' were staged at Beuthen, Hindenburg, Gleiwitz, and elsewhere. ${ }^{34}$

The Gleiwitz Incident was not forgotten by the United States or its allies during the course of World War II. In fact, after the war they specifically included it in the bill of particulars on the conspiracy charge levied against the major Nazi war criminals at Nuremberg, ${ }^{35}$ and the Nuremberg Tribunal heard affidavit testimony regarding it. ${ }^{36}$ There is, further, tantalizing evidence to suggest that the lessons drawn by the Allies from the Gleiwitz

34. Whitney R. Harris, Tyranny On Trial: The Trial Of The Major German War Criminals AT The End Of World WAR II At Nuremberg, Germany, 1945-1946 (Southern Methodist U. Press 1999) (rev. ed.), at 124 .

35. See Nuremberg Trial Proceedings, Vol. 1, Indictment, Section IV(F)(4)(b) ("Accordingly, after having denounced the German-Polish Pact of 1934 on false grounds, the Nazi conspirators proceeded to stir up the Danzig issue, to prepare frontier 'incidents' to 'justify' the attack, and to make demands for the cession of Polish territory. Upon refusal by Poland to yield, they caused German armed forces to invade Poland on 1 September 1939, thus precipitating war also with the United Kingdom and France. ") (internal quotation marks in the original).

36. HARRIS, supra note 34, at 124-26. 
Incident - the foremost being that false flag attacks do occur - shaped the debate about the scope of the right of self-defense under the new U.N. system being planned at the end of the war in San Francisco. Commenting on the drafting history of Article 51 of the U.N. Charter, Thomas Franck noted:

Even the terminology eventually agreed upon, preserving states' 'inherent right of individual or collective self-defence if an armed attack occurs against a Member of the United Nations' (Article 51) was criticized by Archibald MacLeish, within the US delegation, as 'too vague.' He 'recalled that Germany had entered Poland at the beginning of the present war on the pretext that Poland had attacked her. $^{\prime 37}$

Perhaps one reason why few people outside Germany believed Hitler at the time regarding his claim of Polish aggression, and why after the war some statesmen seemed preoccupied with the issue of false flags justifying aggression, was because people remembered the occurrence of a notorious false-flag event early in the Nazi reign, to wit, the Reichstag Fire of 1933. The story is relatively straightforward: The Nazis set fire to the German Parliament (the Reichstag) but blamed the crime on a group of communists in order to justify a mass political witch hunt of the German left, the termination of political and civil liberties for the citizenry at large, and the seizure of totalitarian political control over Germany. ${ }^{38}$ What is important about this false flag for our purposes is the extent to which it was viewed (both at the time and years later at Nuremberg) as an act of state terror having international ramifications.

37. Thomas M. Franck, Recourse To Force: StAte Action AgAinst ThreAts And Armed AtTACKS (Cambridge U. Press 2002), at 48 (footnote omitted).

38. See Nuremberg Trial Proceedings, Vol. 1, Indictment, Section IV(D)(2)(1); John Mage and Michael E. Tigar, The Reichstag Fire Trial, 1933-2008: The Production of Law and History, 60 MONTHLY REV. 24-49, 27-28 (2009). In the early 1960s, under the pressure of Cold War-era anti-communism and a concomitant need to rehabilitate the Nazi-dominated German judiciary, a revisionist account of the Reichstag Fire emerged, according to which one of the defendants (Dutch anarchist Marinus van der Lubbe) had been the sole perpetrator and the Nazis were innocent. See id. at 42-45. This revisionisn - endorsed by none other than the CIA in its effort to defend the "lone assassin" thesis of the Warren Commission against its first-generation critics, see DEHAVENSMITH, supra note 9, at 200 - was conclusively debunked by German scholars following the end of the Cold War and German re-unification. The Nazis did, in fact, do it. See Mage and Tigar, supra. at 45-47. 
The Nazis, after all, had made no secret of their irredentist designs on the post-war peace of Europe as enshrined in the Versailles settlement, ${ }^{39}$ and it was generally believed that any event which would enable them to seize power within Germany would also enable them to begin their march toward the use of aggressive war to re-draw the map of Europe. The feeling was ripe that the international community - in some way, shape or form - had to become involved in litigating the facts of the Reichstag Fire.

The upshot of this international concern was the convening of a citizen-initiated Legal Commission of Inquiry in London in September, 1933, shortly before the commencement of the actual trial of the communist defendants in Germany. Doubting the ability (or willingness) of the German judiciary to afford the defendants a fair trial, the London Commission resolved to hear evidence in the matter and come to a verdict regarding responsibility. ${ }^{40}$ The judges/jurors were nine public-spirited international lawyers, including Arthur Garfield Hays, co-founder of the American Civil Liberties Union. The London Commission - which in key respects should be regarded as the precursor of the many 9/11 truth movements and international citizens’ inquiries that have striven to investigate the $9 / 11$ case, such as the 2011 Toronto Hearings ${ }^{41}$

39. See Nuremberg Trial Proceedings, Vol. 1, Indictment, Section IV(B).

40. See A Mock Trial: Reichstag Fire, Legal Commission, THE COURIER-MAIL, Sept. 16, 1933, http://trove.nla.gov.au/ndp/del/article/1120113 (date accessed 11/17/15).

The international character of the London Commission’s work was clear:

The commission's work was part of an international protest movement, focused not solely upon the pending and impending judicial proceedings in Germany, but also upon the National Socialist seizure of power using the fire as a pretext. The commission had the benefit of an extensive investigation conducted by the World Committee for the Relief of the Victims of German Fascism, which assembled physical evidence and found witnesses.

See Mage and Tigar, supra note 38, at 29.

41. See GOURLEY, THE 9/11 TORONTO RePORT, supra note 13. 
and the 2016 Cooper Union Symposium ${ }^{42}$ - quickly concluded that the Nazis had torched the Reichstag. Twelve years later, the Nuremberg Tribunal agreed that the crime of the Reichstag Fire was relevant to proof of a crime of international dimension (i.e. the crime of aggression), and heard evidence of Nazi responsibility for it. ${ }^{43}$

\section{Operation Northwoods and the Larger Historical Context}

Jim Garrison, the New Orleans prosecutor who for years tried to investigate the assassination of President Kennedy, once remarked, “I’m afraid, based on my own experience, that fascism will come to America in the name of national security." ${ }^{44}$ He was, perhaps, closer to the truth than he realized, for it was during the Kennedy Administration that senior U.S. military officials proposed a false-flag terror operation to justify international war with Cuba that would have made the likes of Reinhard Heydrich proud indeed. The plan was called Operation Northwoods, and it entailed the following:

[T]he plan, which had the written approval of the Chairman and every member of the Joint Chiefs of Staff, called for innocent people to be shot on American streets; for boats carrying refugees from Cuba to be sunk on the high seas; for a wave of violent terrorism to be launched in Washington, D.C., Miami, and elsewhere. People would be framed for bombings they did not commit; planes would be hijacked. Using phony evidence, all of it would be blamed on Castro, thus giving [Joint Chiefs Chairman Lyman Lemnitzer] and his cabal the excuse,

42. See Paul Craig Roberts, A Conference to Clear the Mind of the 9/11 Brainwashing (Sept. 5, 2016), http://www.paulcraigroberts.org/2016/09/05/a-conference-to-clear-the-mind-of-the-911brainwashing.

43. See Ann Tusa and John Tusa, The Nuremberg Trial (MacMillan 1983), at 330 (testimony of Hans Gisevius implicating Goering and Goebbels in the fire).

44. Jim Garrison Interview, Playboy MAGAzINE, October, 1967, available at http://www.whale.to/b/jim_garrison_i.html (date accessed 11/18/15). 
as well as the public and international backing, they needed to launch their war. ${ }^{45}$

Northwoods included proposals for false-flag acts of sabotage of the U.S. Naval Base at Guantanamo Bay, Cuba; the sinking of a U.S. Navy ship in the Guantanamo Bay harbor (casualty lists for which, it was hoped, "would help cause a helpful wave of national indignation”); the blowing up of John Glenn’s rocket ship during his historic space flight; and a highly elaborate deception for simulating the shooting-down of civilian airplanes which involved the retrofitting of aircraft by the CIA, secret landings and disembarkation of passengers, and the surreptitious substitution of drones for aircraft. ${ }^{46}$ On behalf of the Joint Chiefs, Lemnitzer submitted the Northwoods plan to President Kennedy’s Secretary of Defense, Robert MacNamara, whereupon it was summarily quashed. ${ }^{47}$

Manchuria, the Reichstag Fire, and the Gleiwitz Incident were all undisputed, fullyexecuted false flags, but none of them resulted in mass (or even many) casualties. Northwoods, on the other hand, gets us far closer to 9/11 in terms of an historical precedent, as it would have

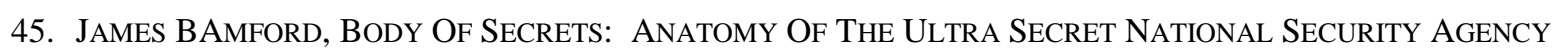
(Doubleday 2001), at 82. The original Operation Northwoods documents were declassified and released to the public in 1997, and are available online at http://nsarchive.gwu.edu/news/20010430/northwoods.pdf.

46. BAMFORD, supra note 45 , at $84-86$.

47. BAMFORD, supra note 45, at 86-87. Some scholars who specialize in the "sociology of conspiracytheorizing" describe Northwoods in a way that trivializes it. Uscinski and Parent, for example, describe Northwoods as an "outlandish conspirac[y]" that "found no reception among decision makers." Joseph E. USCINSKI and Joseph M. PARENT, AMERICAN CONSPIRACY THEORIES, at 32 (Oxford 2014). If by "outlandish" they mean clownish, amateurish, or unserious, Northwoods was quite clearly none of these things. And if by "no reception" they mean to suggest that all (or most) responsible officials within the U.S. Government rejected the plan, they are simply wrong. As far as the historical record tells us, only President Kennedy and his chosen civilian liaison to the military (MacNamara) stood in the way of the plan's execution - no one else. James Bamford puts the issue nicely into perspective:

Lemnitzer was a dangerous - perhaps even unbalanced - right-wing extremist in an extraordinarily sensitive position during a critical period. But Operation Northwoods also had the support of every single member of the Joint Chiefs of Staff, and even senior Pentagon official Paul Nitze argued in favor of provoking a phony war with Cuba. The fact that the most senior members of all the services and the Pentagon could be so out of touch with reality and the meaning of democracy would be hidden for four decades.

Bamford, supra, at 90. 
involved multiple theatres of operation and hundreds, perhaps even thousands, of innocent victims. Moreover, when set within the context of two larger and closely-related categories of state malfeasance - namely, false flags used for domestic political purposes and false pretenses for inter-state war not involving the use of false flags - the 9/11 false-flag scenario becomes scarily thinkable and, if you will, speakable.

As to the former category, we have strong evidence that during the Cold War the U.S. Government (acting through NATO) orchestrated mass-casualty, false-flag terrorism against the civilian populations of Western Europe for the purpose of discrediting the West European Left. The history of this disgraceful episode is not widely known in the West; yet it is indeed very real. In the early stages of the Cold War, NATO and the governments of various West European countries arranged for the formation of a clandestine network of resistance fighters that were intended to be activated to fight against the Soviets in the event they invaded and occupied Western Europe. The project was codenamed Operation Gladio. The backbone of the Gladio network were far-right and neo-Nazi groups working in coordination with carefully compartmentalised sections of the Western security and intelligence services. Although the Soviets never invaded Western Europe, NATO nonetheless activated this network beginning in the late 1960s to commit political assassinations and mass-atrocity terror attacks that were blamed on West European communists. ${ }^{48}$ In 1990, following a series of public revelations by various high-level European officials, the European Parliament alarmingly passed a resolution condemning Gladio in the strongest possible language for its evasion of "all democratic controls,” its illegal interference in the internal political affairs of EU member states, and its

48. For extended literary treatment of Gladio, see PAUL L. WILLIAMS, OPERATION GLADIO: THE UNHOLY ALLIANCE BETWEEN THE VATICAN, THE CIA, AND THE MAFIA (Prometheus Books 2015); RICHARD COTTRELL, GLADIO: NATO'S DAGGER AT THE HEART OF EUROPE (Progressive Press 2010); DANIELE GANSER, NATO'S SECRET ARMIES: OPERATION GLADIO AND TERRORISM IN WESTERN EUROPE (Frank Cass 2005). For documentary treatment, see British Broadcasting Corp., Gladio, https://www.youtube.com/watch?v=GGHXjO8wHsA (1992). 
involvement "in serious cases of terrorism and crime." ${ }^{49}$ U.S. military personnel in NATO were explicitly singled out and condemned for their involvement in the Gladio network. ${ }^{50}$

As to the latter category - false pretenses for inter-state war not involving the use of false flags - we have strong evidence that the U.S. Government lied about being attacked in order to commence full-scale war against North Vietnam in $1964,{ }^{51}$ and lied about the danger of being attacked in order to commence war against Iraq in $2003 .^{52}$ Both sets of lies resulted in wars in which vast numbers of innocent people perished.

Putting all these pieces together, what emerges is a disquieting mosaic showing the very real possibility of a mass-casualty false-flag attack being executed to justify international war. To dismiss this possibility out-of-hand, and to concomitantly belittle the need for the international community to investigate it, not only reflects (as Professor Graeme MacQueen has put $i^{53}$ ) a profound lack imagination; it reflects a rather profound degree of irrationality. Through an appeal to history regarding the reality of past false-flag attacks and mass-casualty state terror, I have tried to pry open the mental space needed for scholars and statesmen to begin

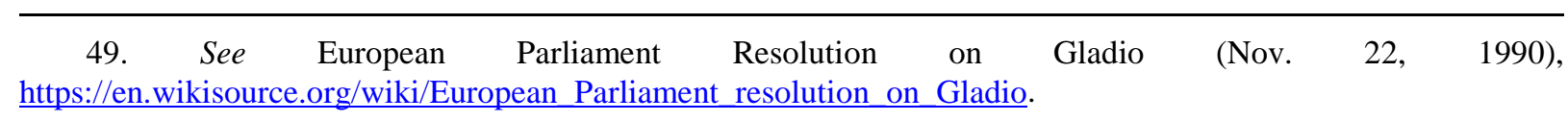

50. See id. If G(2). Perhaps not coincidentally, between 1963 and 1969 (the precise years when Gladio transitioned from a mission of Cold War defense to political terror), NATO was headed by none other than General Lyman Lemnitzer of Operation Northwoods fame, who had been fired as Chairman of the Joint Chiefs of Staff by President Kennedy in 1962 and re-assigned to Europe.

51. The Johnson Administration knowingly lied when it claimed that a U.S. naval vessel had been fired upon by the North Vietnamese in the Gulf of Tonkin.. See John J. MeArsheimer, Why Leaders LiE: The Truth AbOut Lying In InTERnATIONAl Politics (Duckworth Overlook 2011), at 48-49; ERIC Alterman, WHEN PRESIDENTS LIE: A History Of OfFICIAL DECEPTION AND ITS CONSEQUENCES (Viking Penguin 2004), at 160237 (concluding that "[ $\mathrm{t}]$ he violation of public trust and the corruption of public leadership that Tonkin inspired continued to haunt U.S. politics for decades"). As many will be aware, this fabricated incident was the casus belli justifying America’s war in Vietnam.

52. The Bush II Administration knowingly lied when it claimed that Iraq possessed weapons of mass destruction and/or was involved in the 9/11 attacks. MEARSHEIMER, supra note 51, at 49-55; ALTERMAN, supra note 51, at 296-306.

53. Graeme MacQueen, Beyond Their Wildest Dreams: 9/11 and the American Left, TRUTH AND SHADOWS, Mar. 13, 2017, https://truthandshadows.wordpress.com/2017/03/14/911-and-american-left/\#more-4073. 
to engage the reality of false-flag attacks used for egregious purposes. Once we become so engaged, the options for action going forward are clear, as set forth below.

\section{PART II}

\section{HOW WE MIGHT NOW CARE}

\section{A. The Power and the Right to Investigate}

The world community, acting through the United Nations, has the power and the right to investigate the case of $9 / 11$ and come to a judgment regarding it. Article 39 of the U.N. Charter uses peremptory language, providing that "[t]he Security Council shall determine the existence of any threat to the peace, breach of the peace, or act of aggression, and shall make recommendations, or decide what measures shall be taken in accordance with Articles 41 and 42, to maintain or restore international peace and security.”54 Because fraudulent acts of selfdefense will almost always constitute breaches of the peace or armed attacks within the meaning of the Charter, ${ }^{55}$ the Council unquestionably has the right to determine the validity of claims of self-defense. Professor Oscar Schachter stated the obvious when he noted:

The Council has in fact never doubted its right to reject a self-defense claim and call on states making such claims to cease hostilities. It would be absurd to maintain that the use of force under a claim of self-defense cannot be denied and overridden by the Council when it determines that such action is necessary. ${ }^{56}$

54. U.N. Charter art. 39 (emphasis added).

55. See Thomas M. Franck, Terrorism and the Right of Self-Defense, 95 AM. J. INT’L L. 839, 840 (2001).

56. Oscar Schachter, Authorized Uses of Force By the United Nations and Regional Organizations, in Lori F. Damrosch \& David J. Scheffer (eds.), LAW AND FORCE IN THE NEW INTERNATIONAL ORDER (Westview 1991), 65-93, 79. See also Robert J. Delahunty, Paper Charter: Self-Defense and the Failure of the United Nations Collective Security System, 56 CATHOLIC U. L. REV. 871-957, 905 (2007) ("It appears to follow [from Article 39] that the Security Council has the authority to review and override a Member State's claim (even if made in good faith) to have exercised its right of self-defense, and to find instead that such action is itself a breach of the peace, a threat to the peace, or an act of aggression.”). 
In order to enable Council review of self-defense claims, the Charter imposes on selfdefenders both an explicit reporting duty and an implicit evidentiary burden-of- proof. The former requires little commentary, as it is textually-based and fairly straightforward. ${ }^{57}$ The matter of the evidentiary burden is more controversial, as there has long been disagreement on the timing issue (i.e. At what point in a crisis must a self-defending state meet its burden?) That said, there has been near universal agreement that if a self-defending state does not produce satisfactory evidence of a claimed attack or danger prior to acting, it certainly must do so afterwards if and when the Council demands it. Writing in the immediate aftermath of 9/11, Professor Franck - who took the position that Council pre-approval of self-defensive action was not required - also stated: “This reading of Article 51 does not mean that the question of evidence is irrelevant in law... The law does have an evidentiary requirement, but it arises after, not before the right of self-defense is exercised.”58

For all practical purposes, it would seem that the timing of the Security Council's review of a self-defense claim is far less important than the nature and quality of that review. Indeed, I would go so far as to suggest that the Council's authority can well tolerate a state acting in self-defense without prior Council blessing - including in cases where an armed attack is not even imminent - provided the Council is prepared to exercise meaningful review of the state's decision at some point after the fact. This, in fact, is key; the threat of ultimate Council review, through initiation of an independent and effective inquiry, is the only factor capable of making states understand that they undertake self-defense at their peril. Professor Franck may have interpreted the Article 51 right expansively, but in doing so he correctly perceived what

57. U.N. Charter art. 51 ("Measures taken by Members in the exercise of this right of self-defence shall be immediately reported to the Security Council ...”)

58. Franck, supra note 55, at 842 (emphasis in original). See also id. at 840 ("[W]hile the production of ... evidence is essential to sustaining the right, that emphatically is not a condition precedent to its exercise.”). 
was truly important: not Council pre-approval (which has often proved perfunctory), but

determined investigation and assessment of the facts, even if these take place after the self-

defense is underway or even completed. He concluded:

[I]t is less important to fine-tune the legal formula than to agree on institutions and procedures for getting the facts speedily and correctly, on which to base a sensible systemic response to the claim to have acted in...'self-defense.' 59

Unfortunately, "getting the facts speedily and correctly” is exactly what the Security Council has failed to do regarding 9/11 and the host of other events of radical Islamic terror claimed by the West to have occurred in its wake. The Council has in effect rubber-stamped the factual assertions of the Western self-defense claimants and then sent them on their way to self-defend as they see fit. ${ }^{60}$ It has also ignored the stunning evidence that came to light in 2015 indicating that the P3 welcomed the rise of Al-Qaeda's offshoot - the Islamic State (ISIS) - and have used it as a tool for effecting regime change in Syria. ${ }^{61}$ If one were of a

59. Franck, supra note 20, at 60. See also id. at 62 ("It is not merely new agreed upon principles that appear to be needed, but rather an effective, credible process for their implementation: a way to distinguish those instances where a state's recourse to force is factually and contextually justified and those where it is not.”)

In this regard, former Secretary General Kofi Annan arguably fought the wrong battle when he insisted that, in cases of preventative self-defense, states should bring their claims to the Security Council before taking action to protect themselves. See The Secretary-General, In Larger Freedom: Towards Development, Security and Human Rights for All, delivered to the General Assembly, U.N. Doc. A/59/2005 (Mar. 21, 2005), ๆף 124-25 (endorsing the criticism of unilateral preventative action expressed in the 2004 report of the U.N. High-level Panel on Threats, Challenges \& Changes, entitled A More Secure World: Our Shared Responsibility (U.N. Doc. A/59/565 (Dec. 2, 2004), ๆๆ 190-91)).

60. See Security Council Press Statement On Terrorist Attacks in Brussels, SC/12297 (March 22, 2016) (accepting, without independent investigation, Belgium's claim that ISIS carried out terrorist attacks in Brussels on March 22, 2016); S.C. Res. 2249, 7565th mtg., UN Doc S/RES/2249 (Nov. 20, 2015) (same respecting France’s claim that ISIS carried out terrorist attacks in Paris on November 13, 2015); Security Council Press Statement On Terrorist Attack on French Newspaper, SC/11727-PI/2109 (Jan. 7, 2015) (same respecting France's claim that AlQaeda attacked a Paris-based newspaper on January 7, 2015); S.C. Res. 1161, 5223rd mtg., UN Doc S/RES/1611 (July 7, 2005) (same respecting Britain’s claim that terrorist forces struck London on July 7, 2005).

61. See Hugh Roberts, “The Hijackers,” London Review of Books 37, July 16, 2015 (discussing a formerly classified U.S. Defense Intelligence Agency report that not only anticipated the rise of ISIS "but seem[ed] to suggest it would be a desirable development from the point of view of the international 'coalition' seeking regime change in Damascus”). The report can be viewed at: https://www.judicialwatch.org/wp- 
conspiratorial frame of mind, one might suspect that the Council had traded away its right to meaningfully investigate in exchange for states’ agreement to consult it perfunctorily ex ante. Yet regardless of whether a tacit agreement is in place, the Council’s all-too-ready validation of self-defense claims amounts to a gross abdication of its responsibility to ensure that acts of selfdefense are not cleverly-disguised acts of aggression. Its ask-no-hard-questions approach is, in short, a gross abandonment of its core mission.

This core international mission, we do well to recall, is not in any sense dependent on or supplemental to the exercise of national authority. Nowhere in the Charter is there an “exhaustion of national remedies" precondition to the exercise of U.N. jurisdiction over matters of inter-state aggression. This stands in marked contrast to the contingent nature of the jurisdiction of other international bodies, such as the International Criminal Court. ${ }^{62}$ Thus, even though there are grounds for believing that the domestic American investigations into the case of $9 / 11$ have lacked integrity, ${ }^{63}$ the quality of those investigations is legally irrelevant to the question of U.N. jurisdiction, which is original in the fullest sense.

B. Does the Right to Condemn Fraudulent Self-Defense Fall with the (Claimed) Inability to Support Genuine Self-Defense?

Of course, the discussion cannot end there for the simple reason that some critics of the U.N. argue that the Security Council has no core mission left when it comes to policing claims of self-defense. Robert Delahunty, for example, has argued that the limits imposed on the right of self-defense by Article 51 - including post hoc Council review - are no longer binding on

content/uploads/2015/05/Pg.-291-Pgs.-287-293-JW-v-DOD-and-State-14-812-DOD-Release-2015-04-10-finalversion11.pdf

62. See Rome Statute of the International Criminal Court, U.N. DOC. A/CONF. 183/9, art. 17 (1998) (ICC lacks jurisdiction over persons whose cases have been adequately adjudicated at the national level).

63. See supra note 14 and accompanying text. 
states because they were accepted in consideration for a system of collective security that never materialized. He reasons:

[T] he limitations on sovereignty to which member states consented in accepting Article 51 were reciprocal to, and predicated on, the promise of collective security; and ... the persisting and incurable failure of the Charter's collective security system can reasonably be held to relieve member states of their legal obligations to use selfdefensive force within the limitations of Article $51 \ldots{ }^{64}$

Given this (claimed) failure of consideration, Professor Delahunty has argued that nations are entitled "to resume their pre-Charter right of self-defense and even, in light of changed circumstances, to seek to develop more permissive customary norms.” 65

This is an aggressive and powerful argument and, if sound, it would certainly call into question the right of the U.N. to review the validity of the U.S. claim of self-defense stemming from 9/11. Fortunately, the argument is not sound, at least insofar as it relates to the Council's right of review. For the argument ignores the crucial fact that Article 39, although it reads seamlessly, comprises in fact two very different functions. Determining the existence of an act of aggression (the first half of Article 39) involves arriving at a verdict based on facts found through investigation, a quasi-declaratory role likened by Professor Franck to a jury role. Making recommendations and deciding measures to stop aggression (the second half of Article 39), on the other hand, links to and supports the quasi-injunctive policing functions of Article 41 (which sanctions non-military measures to stop aggression) and Article 42 (which sanctions military measures). This duality in Security Council responsibility is nicely portrayed in Professor Franck’s formulation:

64. See Delahunty, supra note 56, at 881.

65. Id. at 872 . 
Failure to adhere to [the use-of-force rules of the Charter] was to be met by decision of the Security Council acting, first as a jury to determine whether there had been a breach of the peace, by whom, and how serious it was, and then deciding what collective measures might appropriately be taken to put matters right. ${ }^{66}$

Even if one agrees arguendo with Professor Delahunty that the Council’s policing function has failed, there is no evidence to suggest that the Council's jury role is similarly dead or handicapped. Injunctive power logically depends on an enforcement mechanism, but the same is not true for the power to declare rights and status: Fact-finding can be undertaken and verdicts rendered even if the declaring body does nothing to enforce its judgment. While the failure of the collective-security system may have implications for the extent of Security Council preemption of self-defensive action, ${ }^{67}$ it has no logical bearing on the question of which entity - the nation-state or the U.N. - has the right to pass judgment on the sufficiency of the facts adduced in support of a claim of self-defense. More importantly still, while states may well have the right to do what they want in pursuit of their self-defense (for who will stop them or help them?), they have no right or entitlement to the label "victim of aggression." The granting of that precious label is reserved exclusively to the international community, acting through the Security Council.

I call that label “precious” because declaratory judgments of rights and status matter. They have intrinsic value regardless of whether they result in injunctive action. To be declared a lawbreaker (or aggressor) means something of significance, even if you don’t end up in jail for it. People (and nations) are not inclined to be seen in public with lawbreakers, or to cooperate with them privately, or to do them any favors. As Professor Delahunty concedes, the

66. Franck, supra note 37, at 20-21.

67. See, e.g., Malvina Halberstam, The Right to Self-Defense Once the Security Council Takes Action, 17 MiCH. J. INT’L L. 229-48 (1996). 
declaratory judgments of the U.N. are viewed as far more legitimate and weighty - because far more representative - than the judgment of any one state. ${ }^{68}$ The failure of the U.S. and Britain to obtain Council authorization for their invasion of Iraq in 2003, for example, delegitimized that military campaign in the eyes of many (at least in the West). ${ }^{69}$ The failure of the U.S. and Britain to obtain Council authorization for their humanitarian intervention in Kosovo in 1999 provoked a crisis so grave that an effort was hurriedly made to redefine the very notion of state sovereignty in order to gain recognition of a new norm of intervention (the "Responsibility to Protect”) that the Council might endorse. ${ }^{70}$ These examples underscore the truth of Professor Franck's conclusion that “[t]here is no realistic alternative to the Council and [General] Assembly as the global juries.”71

Of course, serious discussion needs to take place regarding how best to enable the Council to perform its still-viable jury function. Professor Franck was right to call for "an augmented system of fact-finding reporting to the political organs through the Secretary General.” 72 Indeed, it might well be time to amend Article 43 and replace the concept of standby armed forces with that of standby teams of crime-scene investigators, scientists, engineers, and accountants. ${ }^{73}$ Given that the Council is already firmly in the business of

68. See Delahunty, supra note 56, at 947-48.

69. See id. at 949.

70. See InT’L COMM’n On InTERVEntion And StATE SOVEREIGNTY (2001), Forward, p. VII (“NATO’s intervention in Kosovo in 1999 brought the controversy [surrounding humanitarian intervention] to its head....It was in response to this challenge that the Government of Canada, together with a group of major foundations, announced at the General Assembly in September 2000 the establishment of [this Commission]”).

71. Franck, supra note 20, at 68.

72. Id.

73. Article 43(1) of the Charter provides:

All Members of the United Nations, in order to contribute to the maintenance of international peace and security, undertake to make available to the Security Council, on its call and in accordance with a special agreement or agreements, 
dispatching investigators to probe allegations of war crimes (e.g. Syria, 2013-2016) and illegal weapons development programmes (e.g. Iraq, 2002-2003), deployment of forensic experts to probe claims of aggression would require relatively little in the way of institutional capacitybuilding. What is needed, however, is a both a psychological and de jure paradigm shift that finally and formally uncouples the jury half of Article 39 from the problematic and underrealized policing function enshrined in the second half of Article 39, Articles 41 and 42, and that concomitantly resuscitates (a revised) Article 43.. Such an uncoupling would echo the more flexible adaptation of the Charter that occurred during the early U.N. period, when Article 42 gradually uncoupled from Article 43 once it became clear that the hoped-for Article 43 forces were not going to materialize and that the Council would have to rely on "coalitions of the willing” in order to deploy military force. ${ }^{74}$

Perhaps the final point to make regarding Professor Delahunty’s argument is that he should be careful what he wishes for when he advocates a return to pre-Charter rights of selfdefense. Customary international law in the pre-Charter world reflected a practice of international review and adjudication of self-defense claims every bit as intrusive and tenacious as what has occurred under Article 51. The League of Nations, for example, rejected Japan’s claim that its judgment alone was conclusive on the matter of its need to invade Manchuria in self-defense; hence the mandate and ruling of the Lytton Commisson (discussed supra Part I). ${ }^{75}$ The League similarly rejected Italy's claim of authority to judge its own self-defense needs vis-

armed forces, assistance, and facilities, including rights of passage, necessary for the purpose of maintaining international peace and security.

74. See Franck, supra note 20, at 53-57.

75. See Delahunty, supra note 56, at 906 n.168. 
à-vis Ethiopa during the Abyssinia Crisis of 1934-36. ${ }^{76}$ Finally, the Nuremberg Tribunal rejected the Nazis’ claim that Germany’s judgment was conclusive on the matter of her need to invade Poland and Norway in self-defense, noting that "whether action taken under the claim of self-defense was in fact aggressive or defensive must ultimately be subject to investigation and adjudication if international law is ever to be enforced.” ${ }^{77}$ The Tribunal's arrogation to itself of the ultimate authority to assess Germany's self-defense claims paved the way for judgments of conviction on the "Crimes against Peace" charge against the Nazi leadership.

In short, the reactivation of pre-Charter states’ rights proclaimed by Professor Delahunty in the more immediate aftermath of $9 / 11$ would represent nothing less than a return to full, post hoc international review of self-defense claims. ${ }^{78}$ And since such a return would put us back to where we essentially are, we would be foolish not to use the conventional institutions already in place to carry out the task of international review. ${ }^{79}$

76. See Ian Brownlie, International Law And The Use Of Force By States 242-43 (Oxford U. Press 1963) (citations omitted) (emphasis added):

Italian arguments in justification of the action against Ethiopia were in part based on necessity for action in face of Ethiopian military preparations and attacks. The League of Nations did not consider that this argument was justified by the facts and disregarded further Italian arguments that action to protect vital interests and security was justified and that Italy had the right to decide questions of selfdefence for herself. Italy was stated by the Council and by some governments separately to have acted in violation of the [Kellogg-Briand] Pact.

77. Delahunty, supra note 56, at 906 (quoting from the Nuremberg judgment).

78. Professor Delahunty concedes that the Nuremberg judgment provides "a more coherent and more authoritative formulation of pre-Charter customary law” than any other pre-Charter source. See id. at 905. He nonetheless suggests that the judgment's formulation may require international institutions to presume the correctness of national self-defense claims and/or substantially defer to them. See id. at 906. He does not, however, cite any evidence that supports this suggestion; nor does there appear to be any.

79. If the U.S. were to veto a proposal in the Security Council to open an investigation into 9/11, the proposal could be taken to the General Assembly on the Uniting For Peace procedure (perhaps renamed the Uniting For Truth procedure). See G.A. Res. 377(V), 5th Sess., 302nd Plen. Mtg., U.N. Doc. A/RES/5/377 (Nov. 3, 1950). Given that the Assembly has successfully used Uniting For Peace in a maximalist way - taking charge of aggression-situations such as that presented by the Suez Crisis of 1956, see Franck, supra note 37, at 35-37 - it would certainly seem to be able to use the procedure to achieve the more modest goal of recommending the initiation of an investigation into a self-defense claim such as 9/11. The International Criminal Court might also 


\section{CONCLUSION}

This Article has not attempted to litigate the case of 9/11. Rather, it has sought to show that this very special case merits an objective and independent investigation by the foremost political body of the international community, the United Nations.

Consider, for one moment, what the world would look like were the international community to arrive at a convincing judgment on 9/11. If the official account were confirmed, much of the political toxin injected by the event into the Western body politic would likely drain away. If the official account were falsified and the event adjudged a false-flag attack by a transnational criminal cabal, several things would happen. The War on Terror would come to an immediate halt. Indictments would be issued and criminal trials held until justice was served. Forgiveness of the Muslim world would be sought, and forgiveness would be extended to any Muslims who struck in terror against the West in backlash against the initial fraudulent terrorism of 9/11. Truth and reconciliation à la South Africa would become not only thinkable but realistically possible. And not an ounce of additional police-state control of innocent citizens anywhere in the world would be needed in order to achieve these worthwhile goals.

Either way, on either outcome, the world would be a better place. A genuine international investigation of a horrific and hugely important event is within our power. Mercifully, we have nothing to lose.

have a role to play if the States Parties to the Court - a group of nations that does not include the U.S. - were to amend the Rome Statute to allow for General Assembly-referral jurisdiction on the crime of aggression. 
